\title{
Can Malachite Green Concentrations in Edible Fish Cause Genetic and Hepatic Toxic Effects? An Experimental Study on Adult Albino Rats
}

\author{
Nermeen AM Hassan; Farouk S Elgendy'; Aisha El Mansy²
}

\author{
${ }^{1}$ Forensic Medicine and Clinical Toxicology Department \\ ${ }^{2}$ Histology and Cell Biology Department \\ Faculty of Medicine, Benha University, Benha, Egypt
}

\begin{abstract}
Malachite green (MG) has been widely used as the most efficacious antifungal agent in the fish farming industry. The aim of this study is to evaluate hepatotoxicity of different MG concentrations in edible fish, its mutagenicity and DNA damage on adult albino rats for 4 weeks. Forty eight adult male albino rats were utilized and equally divided into 4 groups, each contains 12 rats. Three concentrations $2.2,30$ and $60 \mu \mathrm{g} / \mathrm{kg}$ body weight (MG) were tested in three independent experiments for 4 weeks. Mutagenicity and hepatotoxicity were evaluated by biochemical, cytogenic, histopathological examination and DNA fragmentation. MG caused an increase of alanine aminotransferase, aspartate amino transferase (ALT and AST), alkaline phosphatase (ALP) levels, and decrease in total protein in animals treated with MG as compared to control. Also, all concentrations of MG were found to induce significant DNA damage in bone marrow cells as assessed by chromosomal aberration. The histopathological changes were highly significant in rats treated with higher doses than other groups and persist even after 2 weeks from MG stoppage. We can conclude that MG and its residues in the edible tissue of fish could not be ignored due to their suspected genotoxicity, hepatotoxicity and DNA fragmentation with apoptotic changes even at lower doses, posing a potential risk for human consumption. This leads us to put strict limitations on its use in the fish farming industry in Egypt.
\end{abstract}

Keywords Malachite green, Genotoxicity, fungicide, Chromosomal aberrations, DNA fragmentation, hepatotoxicity

\section{Introduction}

$\mathrm{M}$ alachite green (MG), N-methylated triphenylmethane, is an organic compound used traditionally as an industrial dye for materials such as silk, wool, jute, leather, and cotton. It is also used extensively as a non permitted food coloring agent especially in several countries (Máchová et al, 1996; Azmi et al., 1998 and Cha et al., 2001). MG is also used as a veterinary drug applied as topical antiseptic or to treat parasites, fungal infections, and bacterial infections in fish and fish eggs in fisheries and has been used as an effective fungicide, especially as a general fish hatchery disinfectant (Mitrowska et al., 2007). Tripathi et al. (2007) also reported singular cases of illegal coloring of foodstuffs (sweets) with MG.

Upon absorption by fish tissue, $M G$ is reduced to leucomalachite green (LMG), which is the persistent form of the dye, retained much longer in muscle and the toxicity exerted by it has greater severity (Mitrowska and Posyniak, 2004). MG residues can persist for longer than 10 days to months in edible fish tissue especially in the liver (Culp and Beland, 1996), while Máchová et al. (1996) reported that LMG persisted in muscle of rainbow trout for 10 months after the treatment of $0.2 \mathrm{mg} \mathrm{MG}$ for 6 days. The elimination of MG and the metabolite LMG in fish muscle occurs very slowly, even at the high temperature of cooking (Chang et al., 2001).

The potential for consumer exposure exists most notably through its use as an antifungal agent in commercial fish hatcheries and as food additive. Banning the use of domestic or imported fish for human consumption if contains $\mathrm{MG} / \mathrm{LMG}$ above $1 \mathrm{ppb}$ (Olesen et al., 2007). Although the use of this dye has been banned in several countries (FSA, 2005; NTP, 2005; FSCJ, 2007 and Olesen et al., 2007) and not 
approved by US Food and Drug Administration, it is still being used in many parts of the world including Egypt due to its low cost, ready availability and efficacy ( Pohjala et al, 2007 and Hameed and ElKhaiary , 2008).

Human exposure to MG and LMG was first documented by Doerge et al. (1998) who analyzed edible flesh from trout purchased from retail outlets in the United Kingdom. MG can cause significant health risk for humans who eat contaminated fish. Also, MG and LMG have been detected in farmed fish imported into the United Kingdom, primarily from Southeast Asia (Srivastava et al., 2004 and Jeong, 2005). Egypt also imported farm fish from Southeast Asia and still used MG as anti fungal in the fish farming industry (Hameed and El-Khaiary, 2008).

Despite its known harmful effects, information on the mechanism(s) of action of MG, its mutagenecity, carcinogenicity and tumor promoter properties is not available. Most of the work on MG induced cellular toxicity was done in vitro, only a few studies have been reported in animal models (Bose et al., 2005; Prasenjit et al., 2006; Minta and WilkZasadna, 2007 and Radko et al. 2011). Although several in vitro studies have reported the toxic effects of MG at higher doses, the purpose of the present study is to focus on study of $\mathrm{MG}$ in vivo is capable of inducing/initiating genotoxic effects at low dose levels (2.2 $\mu \mathrm{g} / \mathrm{Kg}$ body weight) in edible fish measured through hepatic degranulation of DNA and chromosomal aberration in bone marrow cells using male albino rats (available at animal houses) as an experimental model for period of the study, where MG concentrations reported to be $(2.2$ to $>60 \mu \mathrm{g} / \mathrm{kg})$ in edible salmon and trout tissues (Jeong, 2005).

\section{Materials and Methods}

\section{Experimental Animals}

Forty eight male adult albino rats weighing between 120-125 grams were used in this study. These animals were obtained from the animal house of the National Research Center, Giza, in Egypt. The animals were housed in plastic cages, four per cage, and maintained on standard laboratory diet and water ad libitum according to Ethical considerations of studies in experimental animals.

\section{Malachite green}

Malachite green (MG) used in this study was obtained from Sigma-Aldrich Ltd. (Ontario, Canada). Jeong, (2005) reported that presence of $\mathrm{MG}$ is $(2.2$ to $>60$ $\mu \mathrm{g} / \mathrm{kg})$ and LMG is $(5-10,000 \mu \mathrm{g} / \mathrm{kg})$ in edible salmon and trout tissues. Thus, the doses chosen in this study were equal to the minimum, moderate and maximum residue limit of $\mathrm{MG}$ in edible fish $(2.2,30$ and 60 $\mu \mathrm{g} / \mathrm{kg}$ ) equal $0.000011,0.00011$ to 0.00022 of LD50 of MG in rat where oral LD50 was reported to be 275 $\mathrm{mg} / \mathrm{kg}$ b.w. (Clemmensen et al., 1984).

\section{Animal Groups}

Animals were divided equally into 4 experimental groups, 12 rats in each:
- Group I (control): served as control group, each rat received daily distilled water by oral gavage .

- Group II (Low dose): each rat received daily dose of $2.2 \mu \mathrm{g} / \mathrm{kg}$ b.w. of MG by oral gavage .

- Group III (Moderate dose): each rat received daily dose of $30 \mu \mathrm{g} / \mathrm{kg}$ b.w. of MG by oral gavage .

- Group IV (High dose): each rat received daily gavage dose of $60 \mu \mathrm{g}$ / $\mathrm{kg}$ b.w. of MG by oral gavage .

The period of the study: 6 weeks. Samples were taken 2 and 4 weeks from the start of the experiment and 2 weeks after drug stoppage (wash out).

\section{Methods}

\section{Samples}

1. Five $\mu \mathrm{l}$ of blood was drawn up from each rat eyes after 2 and 4 weeks from the start of the experiment and 2 weeks after drug stoppage for biochemical studies.

2. Specimens of liver $(50 \mathrm{mg})$ were taken from all the animals half of specimen fixed with $10 \%$ formaldehyde were prepared for LM examination and other half used for DNA fragmentation assay.

3. Bone marrow cells from femur and tibia were collected.

\section{Biochemical studies}

Five $\mu 1$ of blood was used to assess:

1. alkaline phosphatase (Belfield and Goldberg, 1971);

2. aspartate and alanine amino transferase (AST and ALT) (Reitman and Frankel, 1957); and

3. total protein (Bradford, 1976).

\section{Histopathology studies}

\section{Light microscope examination: Hematoxylin} and Eosin (H\&E)

Samples of liver were taken from all the animals and fixed with $10 \%$ formaldehyde. Then, they were washed with tap water, dehydrated in alcohol and embedded in paraffin. Specimens were taken 2 and 4 wks after treatment of MG and 2 weeks after stop of MG (wash-out) and paraffin sections were prepared for LM examination) (Bancroft and Gamble, 2008).

\section{Chromosome aberrations}

In the end of the treatment, animals of all treated groups were injected intra peritoneal with colchicines $(5 \mathrm{mg} / \mathrm{kg})$ to arrest cell division at metaphase. Two hours after injection, animals were anaesthetized with ether and sacrificed by cervical dislocation for preparation of the chromosomes of bone marrow for chromosomal analysis by using the methodology of Yosida and Amano (1965).

\section{DNA Fragmentation}

The method of DNA fragmentation assay was carried out on groups of animals treated with different doses of 
MG for 4 weeks according to Perandones et al. (1993). Rat liver cells were mechanically dissociated in hypotonic lysis buffer. The cell lysate was centrifuged at $13.000 \times \mathrm{g}$ for $15 \mathrm{~min}$. then, the supernatant containing small DNA fragments was separated immediately and half the supernatant was frozen used for gel-electrophoresis. The other half, as well as the pellet containing large pieces of DNA were used for the colorimetric determination by Diphenylamine (DPA) assay.

\section{DNA fragmentation on agarose gel electrophoresis}

For the preparation of DNA for agarose gel electrophoresis, frozen samples of liver were homogenized in lyses buffer, and centrifuged as described above to separate DNA fragments from intact chromatin. DNA was electrophoresis separated on a $1 \%$ agarose gel containing $0.5 \mu \mathrm{g} / \mathrm{ml}$ of ethidium bromide for $1 \mathrm{~h}$. The Gel was photographed using a Polaroid camera under a UV Transilluminator.

\section{diphenylamine (DPA Assay)}

Quantification of fragmented DNA by

The supernatant containing small DNA fragments was separated from the pellet containing large pieces of DNA. Both supernatants and pellets were used for the colorimetric determination by diphenylamine (DPA) assay. The percentage of DNA fragmentation was expressed by the formula, Where O.D. is the optical density:

DNA Fragmentation $(\%)=\frac{\text { O.D. of supernatant }}{\text { O.D. of supernatant }+ \text { O.D. of pellet }} \times 100$

\section{Statistical Analysis}

The collected data was organized, tabulated and statistically analyzed using SPSS software statistical computer package version 10 . The data are reported as mean \pm SEM. Statistical significance was assessed by ttest for single comparison, or by one way analysis of variance ANOVA (F test) for multiple comparisons. Significance was adopted at $\mathrm{P}<0.05$ for interpretation of results of tests of (Zar, 1999).

\section{Results}

\section{Biochemical analysis}

Table 1 reveals that rats treated with MG developed significant hepatocellular damage as evidenced by a significant elevation in liver enzyme activities (ALT, AST \& ALP) and decrease in total protein content compared to the corresponding control values. Hepatocellular damage post MG treatment with the most pronounced effect for the high dose $(60 \mu \mathrm{g}$ $\mathrm{MG} / \mathrm{kg}$ body weight) than low one and with proportional increase in duration.

\section{Histopathological study}

\section{Light microscope: Hematoxylin and Eosin (H\&E)}

\section{Group (I): Control}

The normal histological structure of control male rat liver showed normal sheets or cords of hepatocytes radiating from a central vein; each a single cell thick, which bifurcated and fused to give a network presented in (Figure 1).

\section{Group (II): Low Dose of MG}

- $\quad 2^{\text {nd }}$ week: Liver sections obtained from rats belonging to the second group showed slight histopathological changes in the hepatic tissue. These changes were manifested in lymphocytic infiltration around the blood vessels, and slight congestion in blood vessels (Figure 2).

- $4^{\text {th }}$ week: Liver sections showed slight dilatation of portal blood vessels and vacuolar degeneration of hepatocytes, hydropic degeneration (H) and multifocal areas of minute aggregations of lymphocytes scattered in the hepatic parenchyma (M) (Figure3).

- $\mathbf{6}^{\text {th }}$ week: Liver sections (wash-out) hepatocyte showed slight dilation of blood vessels (d) and slight hydropic degeneration of hepatic cells $(\mathrm{H})$ (Figure4).

\section{Group (III): Moderate Dose MG}

- $\quad 2^{\text {nd }}$ week: Liver sections showed moderate dilatation of blood vessels, infiltration of mononuclear inflammatory cells (M) and centrilobular vacuolization have been detected in hepatocytes (Figure5).

- $4^{\text {th }}$ week: Liver sections showed sinusoidal congestion and degenerating in hepatic cells were observed. In addition, severe dilatation of blood vessels; infiltration of mononuclear inflammatory cells (M) and diffuse vacuolization have been detected in hepatocytes $(\mathrm{H})$ (Figure 6).

- 6 $^{\text {th }}$ week: Liver sections (wash-out) showed moderate cytoplasmic vacuolization and pyknosis of some hepatocyte (Figure7).

\section{Group (IV): High Dose MG}

- $\quad \mathbf{2}^{\text {nd }}$ week: it showed severe hydropic degeneration, sinusoidal congestion and dilatation and severe infiltration of mononuclear inflammatory cells were observed (Figure8).

- $4^{\text {th }}$ week: it showed detrimental changes with severe effects of high dose, since sinusoidal congestion and degenerating in hepatic cells were observed. In addition, remarkable hypertrophy and vacuolization followed by necrosis, fibrosis and cirrhosis have been detected in hepatocytes. Notice loss of 
architecture (Figs. 9). In other parts of the liver tissue, hydropic degeneration and vacuolation in the hepatocytes, complete degenerated hepatocytes and oedematous blood vessels were noticed.

- $\mathbf{6}^{\text {th }}$ week: liver sections (wash-out) showed areas of liver cells necrosis, diffuse lymphocytic infiltration and atrophy and areas of proliferation have been detected in hepatocytes (Figure10).

\section{Cytogenetic results: Chromosome aberrations}

A significant increase $(\mathrm{P} \leq 0.01)$ in the chromosomal aberration in treated rats as compared to control animals indicating mutagenic behavior of MG (Table 2) Structural chromosomal aberrations observed after exposure of MG even at lower doses $(2.2 \mu \mathrm{g} / \mathrm{kg})$ were in the form of chromatid breakage (fragments, breaks and gaps). A dose-dependent increase in chromosomal aberrations reached a maximum of $14.2 \pm 0.68$ ( $p<$ 0.01 ) after repeated treatments for 4 weeks with the tested dose $60 \mu \mathrm{g} / \mathrm{kg}$ b. wt (Figure 11).

\section{DNA Fragmentation assay}

Table (3) demonstrates the mean percentage of DNA fragmentation induced in rat liver cells after concurrent administration of $\mathrm{MG}$ for $4 \mathrm{wks}$. Compared to control group $\mathrm{MG}$ induced dose dependent increase in liver percentages of genomic DNA fragmentation. Effect of MG administration induced DNA damage was evaluated by measuring the level of genomic DNA fragmentation using the diphenylamine assay. Agarosegel electrophoresis confirmed significant genomic DNA fragmentation by detecting DNA ladders on agrose gel electrophoresis (Figure 12).

Table (1): Effect of Malachite green on liver function enzymes and total protein in male After Oral Administration of Different Doses of Malachite Green For period of the study in adult albino rats

\begin{tabular}{|c|l|l|c|c|c|c|}
\hline Group & Dose $(\boldsymbol{\mu g} / \mathbf{K g})$ & Time/day & ALT(IU/L) & AST (IU/I) & ALP & Total protein (mg/min) \\
\hline Group I & & & $42.56 \pm 2.26$ & $74.25 \pm 1.62$ & $115.14 \pm 1.86$ & $8.33 \pm 1.2$ \\
\hline \multirow{3}{*}{ Group II } & $2.2 \mu \mathrm{g} / \mathrm{kg}$ & $2 \mathrm{wks}$ & $71.34 \pm 1.13^{*}$ & $98.68 \pm 1.53^{*}$ & $122.1 \pm 1.8^{*}$ & $7.1 \pm 0.24^{*}$ \\
\cline { 2 - 7 } & $2.2 \mu \mathrm{g} / \mathrm{kg}$ & $4 \mathrm{wks}$ & $95.15 \pm 0.75^{* *}$ & $162.83 \pm 2.7 * *$ & $137.74 \pm 1.62^{* *}$ & $6.82 \pm 0.81^{* *}$ \\
\cline { 2 - 7 } & Wash out & $2 \mathrm{wks}$ & $86.74 \pm 2.13^{* *}$ & $150.72 \pm 1.62^{* *}$ & $132.8 \pm 2.92^{* *}$ & $7.62 \pm 0.36^{*}$ \\
\hline \multirow{3}{*}{ Group III } & $30 \mu \mathrm{g} / \mathrm{kg}$ & $2 \mathrm{wks}$ & $82.21 \pm 1.02^{*}$ & $113.478 \pm 1.18^{*}$ & $143.2 \pm 0.90^{*}$ & $6.5 \pm 0.37^{*}$ \\
\cline { 2 - 7 } & $30 \mu \mathrm{g} / \mathrm{kg}$ & $4 \mathrm{wks}$ & $109.71 \pm 1.54^{* * *}$ & $193.28 \pm 1.60^{* *}$ & $179.61 \pm 1.33^{* *}$ & $5.91 \pm 0.31^{* *}$ \\
\cline { 2 - 7 } & Wash out & $2 \mathrm{wks}$ & $97.36 \pm 1.22^{* *}$ & $157.87 \pm 1.80^{* *}$ & $156.3 \pm 1.58^{* *}$ & $6.12 \pm 0.22^{*}$ \\
\hline \multirow{3}{*}{ Group IV } & $60 \mu \mathrm{g} / \mathrm{kg}$ & $2 \mathrm{wks}$ & $121.19 \pm 1.85^{* * *}$ & $213.72 \pm 1.6^{* *}$ & $165.82 \pm 2.04^{* * *}$ & $5.58 \pm 1.12^{* *}$ \\
\cline { 2 - 7 } & $60 \mu \mathrm{kg}$ & $4 \mathrm{wks}$ & $265.56 \pm 1.51^{* * *}$ & $360.21 \pm 1.63^{* * *}$ & $193.42 \pm 1.91^{* * *}$ & $4.35 \pm 0.67^{* * *}$ \\
\cline { 2 - 7 } & Wash out & $2 \mathrm{wks}$ & $242.38 \pm 1.43^{* * *}$ & $341.3 \pm 1.55^{* * *}$ & $174.87 \pm 1.84^{* * *}$ & $5.13 \pm 0.85^{* * *}$ \\
\hline
\end{tabular}

Values are expressed as mean \pm SEM, $* p<0.05 ; * * p<0.01 ; p<0.001 * * * v / s$ Control. MG Data were analyzed by using one way ANNOVA.

Table (2): Number and Percentage Of Chromosomal Aberration In Rat Bone Marrow Cells After Oral Administration of Different Doses of Malachite Green For period of the study in adult albino rats

\begin{tabular}{|c|c|c|c|c|c|c|c|c|c|c|c|}
\hline \multirow[t]{2}{*}{ Groups } & \multirow[t]{2}{*}{$\begin{array}{l}\text { Dose } \\
(\mu \mathrm{g} / \mathrm{Kg})\end{array}$} & \multirow[t]{2}{*}{\begin{tabular}{|l} 
Period \\
(week)
\end{tabular}} & \multirow{2}{*}{$\begin{array}{l}\text { Abnormal } \\
\text { metaph } \\
\text { (No.) }\end{array}$} & \multicolumn{2}{|c|}{$\begin{array}{c}\text { Metaphases with } \\
\text { Aberration }\end{array}$} & \multicolumn{4}{|c|}{ Number \& percentage of metaphases with } & \multirow{2}{*}{$\begin{array}{c}\text { More than } \\
1 \\
\text { aberration }\end{array}$} & \multirow{2}{*}{$\begin{array}{c}\text { Mitotic } \\
\text { somatic } \\
\text { cell } \\
\pm \text { SEM }\end{array}$} \\
\hline & & & & $\begin{array}{c}\text { Including } \\
\text { gap } \\
\text { Mean } \pm \text { SE } \\
M\end{array}$ & \begin{tabular}{|} 
Excluding \\
gap \\
Mean \pm SE \\
$M$ \\
$M$
\end{tabular} & $\begin{array}{c}\text { Break } \\
\text { \&/or } \\
\text { fragment }\end{array}$ & $\begin{array}{c}\text { Chromatid } \\
\text { Gap }\end{array}$ & Polyploidy & Deletion & & \\
\hline Group I & & & 24 & $4.8 \pm 0.2$ & $2.4 \pm 0.24$ & $6(1.2)$ & $12(2.4)$ & $2(0.4)$ & $4(0.8)$ & - & $14 \pm 0.1$ \\
\hline \multirow[t]{3}{*}{ Group II } & $2.2 \mu \mathrm{g} / \mathrm{kg}$ & $2 \mathrm{wk}$ & 28 & $5.6 \pm 0.74 *$ & $3.6 \pm 0.74$ & $11(2.4)$ & $11(2.0)$ & $2(0.4)$ & $4(0.8)$ & - & \multirow{3}{*}{$12 \pm 0.2 *$} \\
\hline & $2.2 \mu \mathrm{g} / \mathrm{kg}$ & $4 \mathrm{wk}$ & 34 & $6.8 \pm 0.37 *$ & $5.4 \pm 0.24 *$ & $13(3.2)$ & $9(2.4)$ & - & $6(1.2)$ & - & \\
\hline & Wash out & $2 \mathrm{wk}$ & 31 & $6.2 \pm 0.56^{*}$ & $5.9 \pm 0.31 *$ & $12(1.3)$ & $8(0.3)$ & $1(0.1)$ & $3(0.7)$ & - & \\
\hline \multirow[t]{3}{*}{ Group III } & $30 \mu \mathrm{g} / \mathrm{kg}$ & $2 \mathrm{wk}$ & 33 & $5.8 \pm 0.96^{*}$ & $4.7 \pm 0.74$ & $14(1.6)$ & $11(2)$ & $2(0.5)$ & $5(0.6)$ & $1(0.3)$ & \multirow{3}{*}{$9 \pm 0.2 * *$} \\
\hline & $30 \mu \mathrm{g} / \mathrm{kg}$ & $4 \mathrm{wk}$ & 43 & $8.3 \pm 0.38 *$ & $6.6 \pm 0.24 *$ & $18(2.4)$ & $14(1.4)$ & $4(1.1)$ & $7(1.9)$ & $4(0.8)$ & \\
\hline & Wash out & $2 \mathrm{wk}$ & 39 & $7.9 \pm 0.44 *$ & $6.4 \pm 0.33^{*}$ & $17(1.7)$ & $13(0.7)$ & $3(0.3)$ & $6(1.2)$ & $3(0.7)$ & \\
\hline \multirow[t]{3}{*}{ Group IV } & $60 \mu \mathrm{g} / \mathrm{kg}$ & $2 \mathrm{wk}$ & 38 & $8.6 \pm 0.7 * *$ & $7.8 \pm 0.58 *$ & $11(2.4)$ & $12(3.6)$ & $1(0.2)$ & $5(1)$ & $2(0.4)$ & \multirow{3}{*}{$3 \pm 0.1 * *$} \\
\hline & $60 \mu \mathrm{g} / \mathrm{kg}$ & $4 \mathrm{wk}$ & 57 & $14 \pm 0.7 * *$ & $10 \pm 0.9 * *$ & $19(5.8)$ & $15(3.2)$ & $8(1.6)$ & $5(1)$ & $8(1.6)$ & \\
\hline & Wash out & $2 \mathrm{wk}$ & 49 & $12 \pm 0.9 * *$ & $9.8 \pm 0.86 *$ & $16(2.0)$ & $12(2.6)$ & $1(0.2)$ & $8(1.6)$ & $5(1)$ & \\
\hline
\end{tabular}

* Significant at $p \leq 0.05$. ** Significant at $p \leq 0.01$.versus to control (t-test). MG Data were analyzed by using one way ANNOVA. 
Table (3) Mean percentage of DNA fragmentation in rat bone-marrow cells after oral dose treatment with different doses of Malachite green for different periods

\begin{tabular}{|l|l|c|c|}
\hline \multicolumn{1}{|c|}{ Group } & Dose & Time/day & DNA Fragmentation (mean\% $\mathbf{0}$ SEM) \\
\hline Group I & & & $3.85 \pm 0.8$ \\
\hline \multirow{5}{*}{ Group II } & $2.2 \mu \mathrm{g} / \mathrm{kg}$ & $2 \mathrm{wk}$ & $8.37 \pm 1.02^{*}$ \\
\cline { 2 - 4 } & $2.2 \mu \mathrm{g} / \mathrm{kg}$ & $4 \mathrm{wk}$ & $17.2 \pm 0.96^{* *}$ \\
\cline { 2 - 4 } & Wash out & $2 \mathrm{wk}$ & $16.7 \pm 1.33^{* *}$ \\
\hline \multirow{5}{*}{ Group III } & $30 \mu \mathrm{g} / \mathrm{kg}$ & $2 \mathrm{wk}$ & $15.6 \pm 1.1^{*}$ \\
\cline { 2 - 4 } & $30 \mu \mathrm{g} / \mathrm{kg}$ & $4 \mathrm{wk}$ & $24.36 \pm 1.12^{* *}$ \\
\cline { 2 - 4 } & Wash out & $2 \mathrm{wk}$ & $20.44 \pm 1.47^{* *}$ \\
\hline \multirow{3}{*}{ Group IV } & $60 \mu \mathrm{g} / \mathrm{kg}$ & $4 \mathrm{wk}$ & $24.76 \pm 1.31^{* *}$ \\
\cline { 2 - 4 } & $60 \mu \mathrm{g} / \mathrm{kg}$ & $4 \mathrm{wk}$ & $43.28 \pm 1.08^{* * *}$ \\
\cline { 2 - 4 } & Wash out & $2 \mathrm{wk}$ & $39.41 \pm 1.12^{* * *}$ \\
\hline
\end{tabular}

* Significant at $p \leq 0.05$. ** Significant at $p \leq 0.01$, *** Significant at $p \leq 0.001$.versus to control. (t-test).

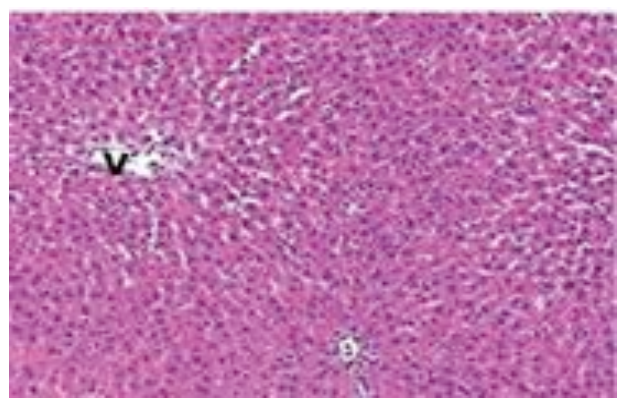

Figure (1): A photomicrograph of a liver section from Group I (control) showing hepatocytes with central vesicular nuclei and granular acidiophlic cytoplasm radiating from central vein (V). Notice the presence of many binucleated cells around blood sinusoids. [H\&E X400]

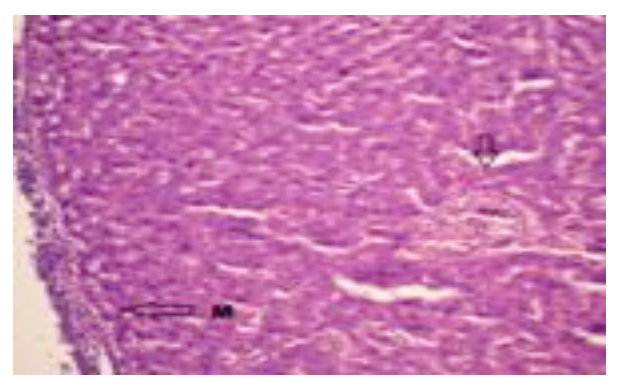

Figure (2): A photomicrograph of a liver section from adult male rat from Group II: (2wks after treatment of MG), showing slight lymphocytic infiltration (F) with dilated blood sinusoids (arrow). [H\&E X400]

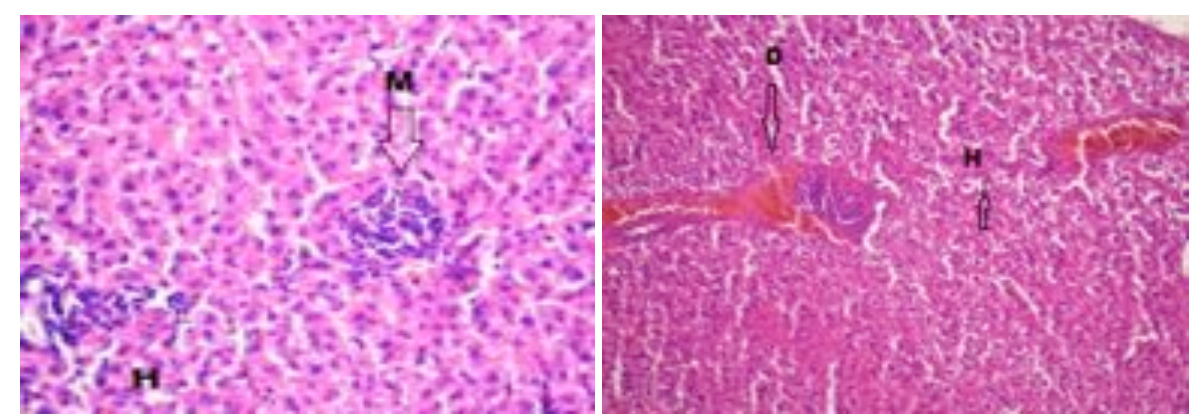

Figure (3): A photomicrograph of a liver section from adult male rat from Group II: (treated 4wks after treatment of MG), showing slight dilatation of portal blood vessels and vacuolar degeneration of hepatocytes, hydropic degeneration $(\mathrm{H})$ and multifocal mild to moderate lymphocytic infiltration scattered in the hepatic parenchyma (M). [H\&E X400] 


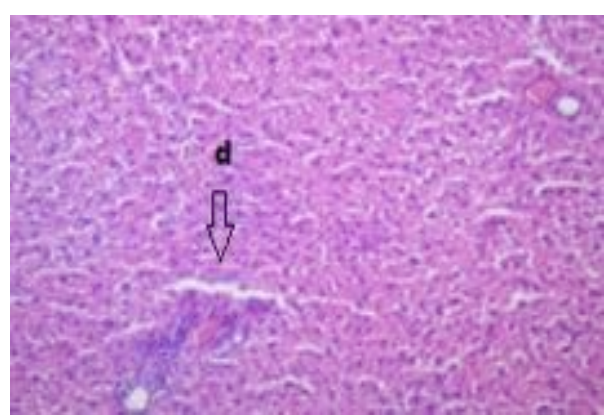

Figure (4): A photomicrograph of a liver section from adult male rat from Group II: (2wks after stop treatment of MG), showing slight dilation of blood vessels (d) and slight hydropic degeneration of hepatic cells. [H\&E X 400]
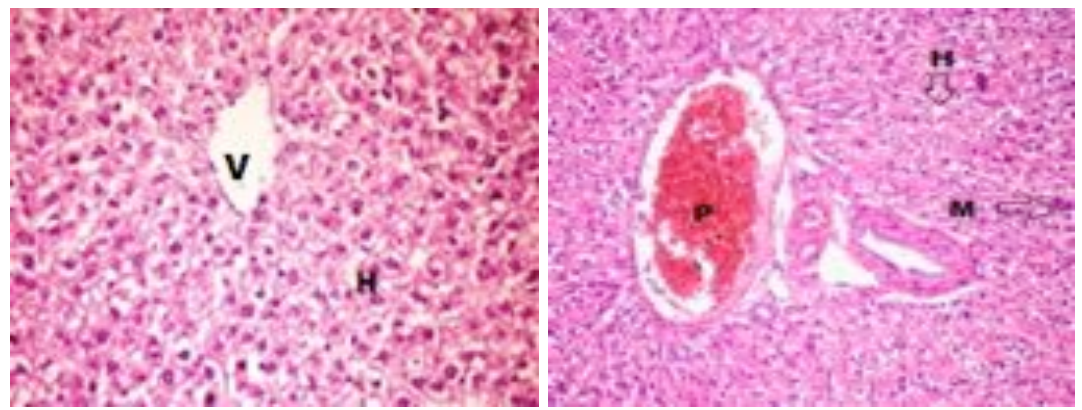

Figure (5): A photomicrograph of a liver section from adult male rat from Group III: (treated with MG after 2 wks), showing moderate dilatation of blood vessels, infiltration of mononuclear inflammatory cells (M) and with vaculation of hepatocyte $(H) \&$ sinusoidal dilatation. [H\&E X 400]

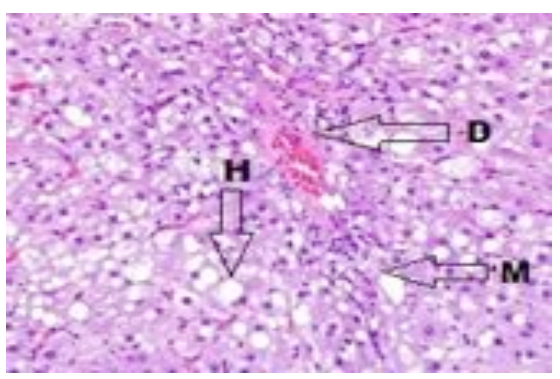

Figure (6): A photomicrograph of a liver section from adult male rat from Group III: (4wks after treatment of MG), showing sinusoidal congestion, degenerating in hepatic cells, dilatation of blood vessels, infiltration of mononuclear inflammatory cells $(M)$ and diffuse vacuolization have been detected in hepatocytes $(H)$. [H\&E X400]

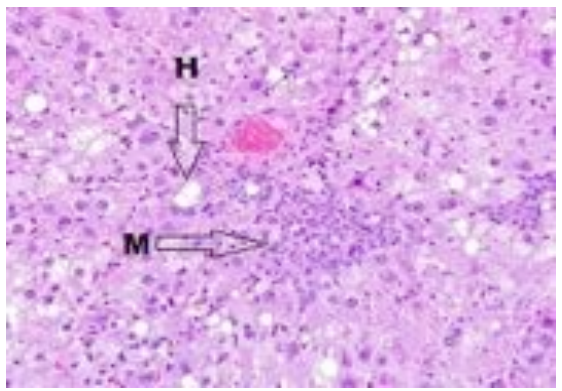

Figure (7): A photomicrograph of a liver section from adult male rat from Group III: (2wks after stop treatment of MG), showed moderate dilatation of blood vessels, moderate cytoplasmic vacuolization and pyknosis of some hepatocyte. [H\&E X 400] 

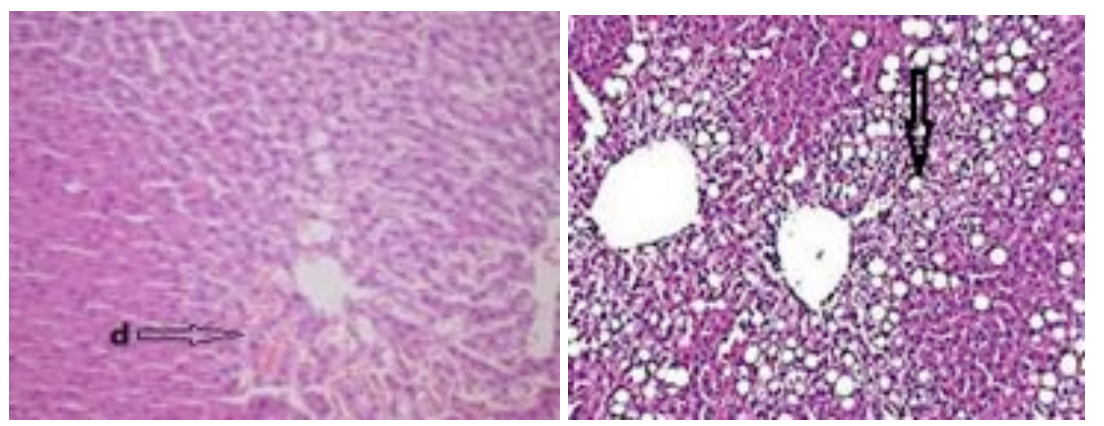

Figure (8): A photomicrograph of a liver section from adult male rat from Group IV: (2wks after treatment of MG), showing severe hydropic degeneration, sinusoidal congestion and dilatation of blood vessels (d) and mononuclear inflammatory cells were observed. [H\&E X400]
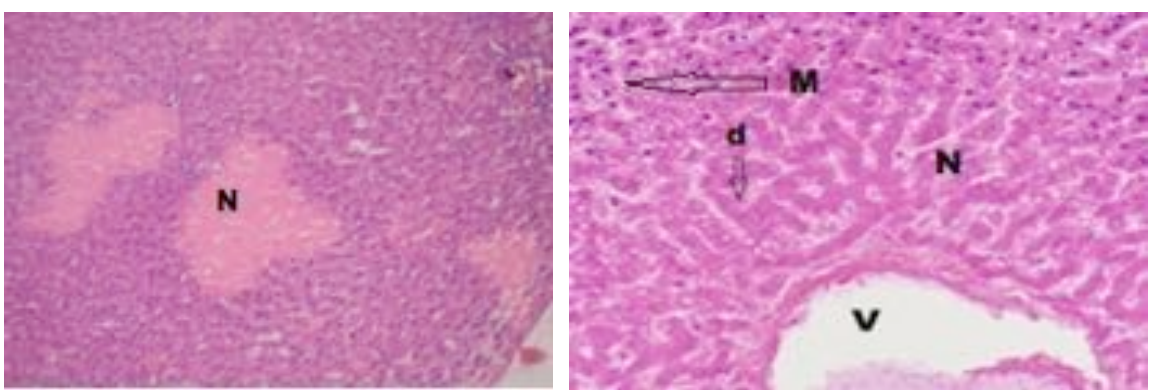

Figure (9): A photomicr0ograph of a liver section from adult male rat from Group IV: (4wks after treatment of MG), showing detrimental changes with severe effects of high dose, since sinusoidal congestion and degenerating in hepatic cells were observed. In other parts of the liver tissue, remarkable hypertrophy and vacuolization followed by extensive necrosis, fibrosis and cirrhosis have been detected in hepatocytes. Notice loss of architecture. [H\&E X400]
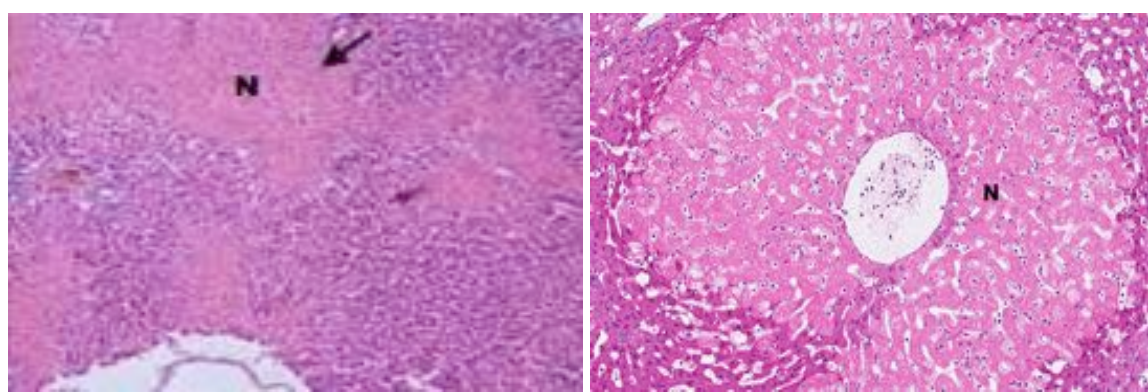

Figure (10): A photomicrograph of a liver section from adult male rat from Group IV: (2wks after stop treatment of MG), showing areas of liver cells necrosis (N), diffuse lymphocytic and mononuclear infiltration (M) and atrophy and areas of proliferation have been detected in hepatocytes. [H\&E X400] 

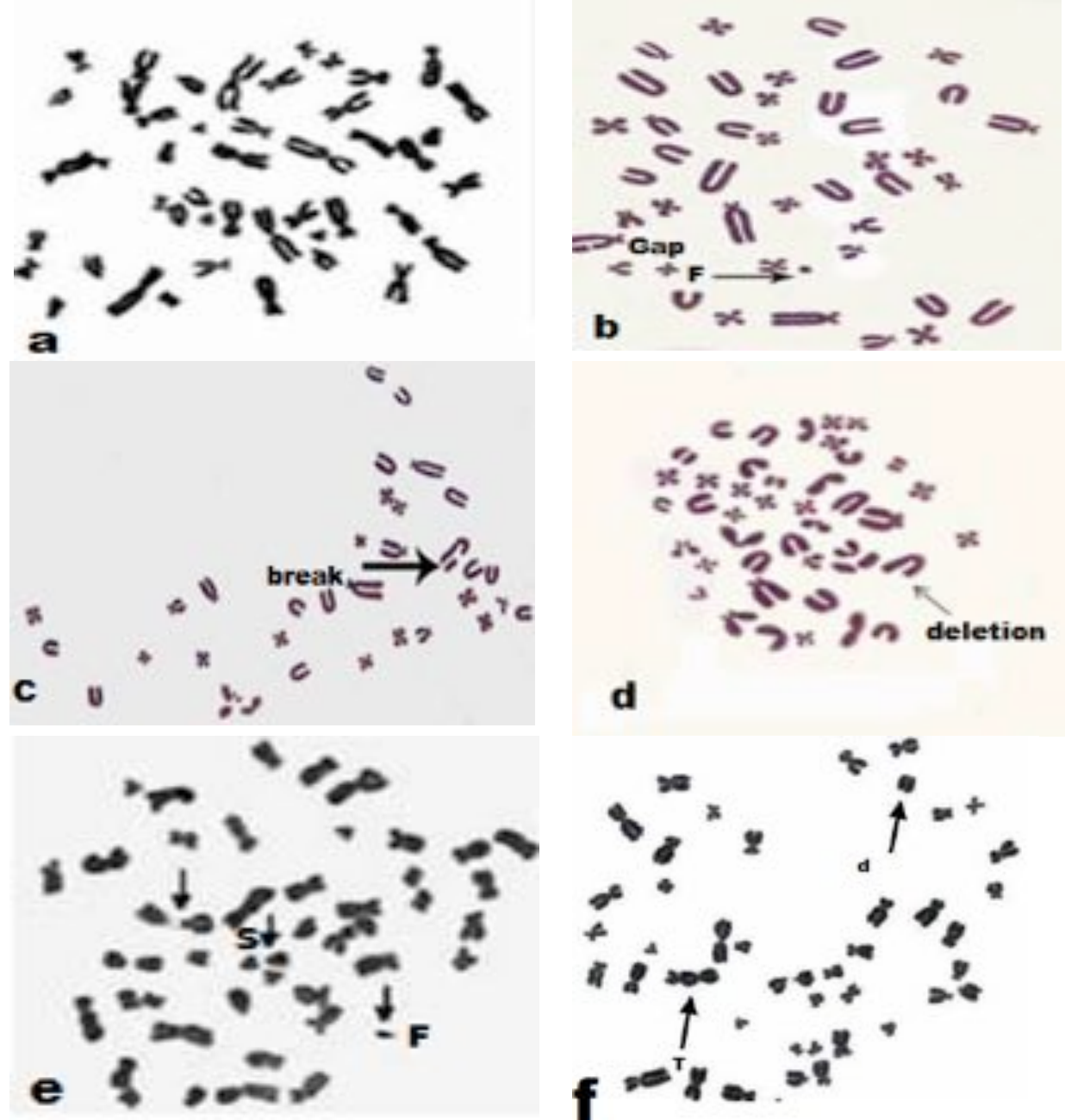

d

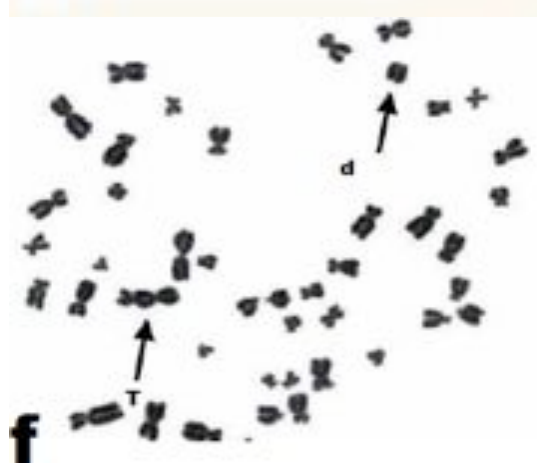

Figure (11): Photomicrograph showing different types of chromosomal aberration. (a) A photomicrograph of well spread metaphases Group I showing control metaphase (b) \& (c) photomicrograph of well spread metaphases Group II showing chromosome fragments (F) and chromatid gap (G). (d) \& (e) A photomicrograph of well spread metaphases Group III showing fragmentation, satellite and breakage. (f) A photomicrograph of well spread metaphases Group IV showing chromosome deletion, fragmentation, break, stickiness and tetraploidy. [X1000]
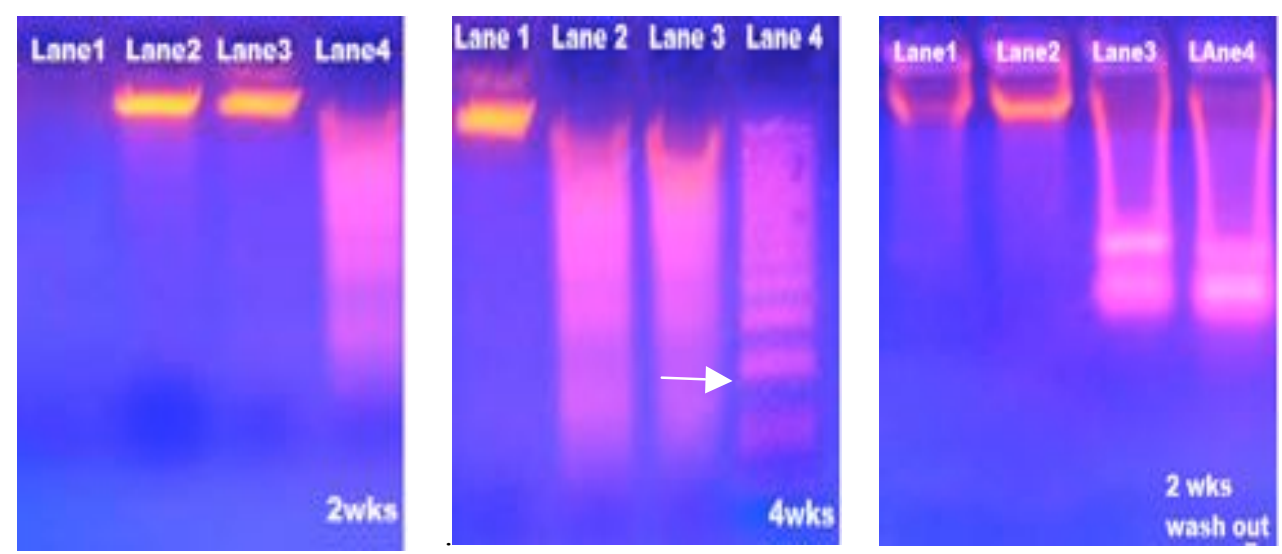

Figure (12): Gel electrophoresis of extracted DNA from rat liver treated with MG showing DNA fragmentation of rat liver cells of different groups on gel electrophoresis with laddering pattern $(\rightarrow$ ) on moderate and high dose of MG $(30 \& 60 \mu \mathrm{g} / \mathrm{kg})$. Lane 1: (control group), lane 2: (group II) low dose, lane 3: (group III) moderate dose and lane 4: (group IV) high dose.

\section{Discussion}

The present study indicated that treating animals with the three doses of malachite green caused significant increase in the serum levels of ALT, AST and ALP; the drastic effect was at higher dose and with long duration treatment. Similar results were reported by Culp et al (1999), who found significant increase in 
both serum AST and ALT of rats fed on MG dye for 4weeks, they attributed these changes in liver function to hepatocellular impairment which subsequently caused the release of greater levels of intracellular enzymes into the blood.

The AST and ALT are known important biomarkers for assessment of $\mathrm{MG}$ hepatotoxicity. Hepatic necrosis or membrane damage releases the enzyme into circulation and hence it can be measured in the serum. Thus, Elevated levels of serum enzymes are indicative of cellular leakage and loss of functional integrity of cell membrane in liver. Botros et al., (2007) and Das et al., (2013), reported that the MG induced hepatotoxicity in mice was indicated by the sharp increase of serum ALT and AST levels. A high level of ALT is more specific to the liver, and is thus a better parameter for detecting liver injury. ALP and total protein levels on other hand are related to the function of hepatic cell. Increase in serum level of ALP is due to increased synthesis, in presence of increasing biliary pressure (Li and Hotchkiss 1995and Mustacich and Powis, 2000).

On the other hand Mittelstaedt et al. (2004) found low level of ALT, AST and ALP in liver tissue after $M G$ treatment. The decrease in transaminases levels providing additional support for the side effect of the MG on mitochondria of the hepatic cells as it is the subcellular localization of transaminases. The low level of ALP in liver tissue post MG treatment was observed by (El-Aasar et al., 1998) and (AbdelRahman et al 1993). This was attributed to the irritation of liver cells by toxins or due to increase loss of intracellular enzyme by diffusion through cell membrane.

In the present study total protein content showed a significant reduction. This could be attributed to the cellular damage caused by MG. The significant decrease in total protein content is mainly due to the increase in messenger RNA degradation which is the possible cause for the hypoalbuminmia. Moreover, there is evidence of conformational changes of serum albumin induced by its interaction with low molecular weight of dyes, which appears to affect the secondary and tertiary structure of albumin (Zahn and Braunbeck, 1995; Henderson et al., 1997; Schwaiger et al., 1997; and Hushcha et al., 2000).

In the present study, the histolopathological results of rats treated with the MG represented by detrimental effects in liver, sinusoidal congestion and focal necrosis in liver, hypertrophy and vacuolization and loss of hepatic architecture followed by necrosis, fibrosis and cirrhosis have been observed in hepatocytes. These findings were in accordance with the experimental studies conducted by Srivastava et al., (2004) who postulated that the liver fibrosis is a consequence of chronic liver injury from MG. In the liver there is an increased deposition of extracellular matrix (ECM) in perisinusoidal and periportal spaces.
The accumulation of ECM proteins distorts the hepatic architecture by formation of fibrous scar and subsequent development of nodules regenerating hepatocytes defines cirrhosis.

In agreement with these results, Bose et al. (2005) observed that MG caused detrimental effects in fish liver, gill, kidney, intestine, gonads and pituitary gonadotropic cells.

Santos et al., (2012) reported that lower concentrations of MG caused no changes, but in higher concentrations (above $50 \mu \mathrm{g} / \mathrm{kg}$ ), the sinusoidal capillaries were congested, the hepatocytes presented hypertrophic with changes in cytoplasmatic granulation.

On the other hand, Onell et al. (2000) who found that histological examination of livers from $\mathrm{MG}$ intoxicated rats revealed that hepatocytes denaturation and necrosis were not obvious and pseudolobules were not found.

The present study revealed that MG treated rats exhibited genotoxic effects as evidenced from increase in the percentage of chromosomal aberrations in a dose and time dependent matter. Cytogenetic analysis for chromosomal aberrations like breaks, deletion, fragmentation, satellite associations and gaps can be used to monitor MG induced genotoxic effects on chromosomes under in vivo conditions. These results are in agreement with previous studies that reported the induction of structural and numerical aberrations (Fessard et al., 1999; Mahudawala et al., 1999; and Kumar et al., 2007).

In this study, various chromosomal aberrations were recorded in bone marrow cells of rat male. The numerical aberration was only polyploidy. Total structural chromosomal aberrations were breaks, satellite associations and gaps. There were significant increases in both structural and numerical chromosomal aberrations, when compared with control after using the mentioned three MG doses. The increase in structural chromosomal aberration was dose dependent. The highest change value $(57 \pm 1.33$, p $\leq$ $0.01)$ was obtained by the high dose $(60 \mu \mathrm{g} / \mathrm{kg})$ as compared with control. The current work also indicated the apoptotic changes induced by MG in rat liver cells by measuring the percentage of DNA fragmentation colorimetrically with (DPA) assay and confirming it with agarose gel-electrophoresis (Donya et al., 2012)

In agreement with these results, Das et al., (2013) revealed that MG treated mice caused genotoxic effects as evidenced from the increased numbers of chromosomal aberrations. There was an elevated frequency of micronuclei and an increase in the mitotic index of the bone marrow cells in MG treated mice in comparison to the vehicle control animals. Occurrence of increased micronuclei in the MG treated mice could be due to their effect on the chromosomes in different stages of cell cycle or due to their clastogenic effect. 
Mittelstaedt et al. (2004) found that MG induced elevation in the frequency of Sister Chromatid Exchange (SCE's) in mouse bone marrow cells beside increase in the percentage of chromosomal aberrations in somatic in a dose and time dependent matter. Data relating to the mutagenicity of $\mathrm{MG}$ are controversy.

Manjanatha et al. (2004) disagree with these results. They concluded that although MG can produce DNA adducts in the liver of female and male rats and female mice it was not genotoxic in conventional in vitro and in vivo assays.

In the present study, significant DNA damage $(43.28 \pm 1.08, \mathrm{p} \leq 0.001)$ was observed in MG treated rats by increasing the dose of MG treatment and period of study exhibiting acute hepatotoxicity as compared to control. Cells with damaged display increased migration of DNA fragments. The present study indicated DNA damage in $\mathrm{MG}$ treated rats as evidenced by decreased levels of protein content compared to control animals. These results are in agreement with other studies (Kassie et al., 2000; Culp et al., 2002; Bose et al., 2005; and Culp et al., 2006). DNA damage may be attributed to elevated oxidative stress. Apoptosis is a form of programmed cell death shown to play a key role in normal development and oncogenesis. Because DNA fragmentation in apoptosis is internucleosomal, a characteristic "DNA ladder" can be visualized on gel electrophoresis as a series of fragments (Perandones et al., 1993).

This result was in the same line with Gupta et al. (2003); Bose et al. (2005); and Jiang et al. (2009) who observed a dose-dependent increase in DNA damage in the form of 'tail moment' by MG, at all the concentrations tested indicative of induction of strand breaks as well as alkali-labile sites. The same Authors reported that MG induced apoptosis both at 0.025 and $0.05 \mathrm{mg} / \mathrm{ml}$ studied by flow cytometry on the basis of hypodiploid peak formation below G0/G1 (Jamil, 2001 and Naravaneni and Jamil, 2005).

The dramatic effects of MG on protein level and the activity of liver enzymes are supported by the results on DNA fragmentation. The liver DNA in MG treated animals was found to be greatly degraded compared to control animals, which may explain the deleterious effect of $\mathrm{MG}$ on the level of cellular proteins and enzymes. This result is in agreement with previous results of Culp et al., (2006) and Das et al., (2013).

De Angelis et al., (2003) and Stammati et al., (2005) conducted studies to ascertain the in vitro toxicity of $\mathrm{MG}$ and $\mathrm{LMG}$ in two human tumor cell lines (Caco-2 and HEp-2). It was concluded that $\mathrm{MG}$ reduces proliferation capability and impairs mitochondrial activity.

Bose et al., (2005) founded out that MG is able to cause DNA damage, to induct the apoptosis and G2/M cell cycle arrest and causes elevated phosphorylation of ERK1 (Extracellular Regulated
Kinase) and JNK1 (Jun-N-terminal Kinase) in exposed SHE cells.

Mittelstaedt et al., (2004) and Culp et al., (2006) explained the mechanism of DNA damage by $\mathrm{MG}$; it is caused by LMG which undergoes a similar $\mathrm{N}$-demethylation by cytochrome P-450. Also, it has been previously reported that nuclei and mitochondria act as major targets of MG toxic action, probably by increasing the generation of free radicals, lipid peroxidation and DNA adducts formation (Hidayah et al., 2013).

\section{Conclusions}

The preceding account of MG revealed that this dye has now become one of the most debated and controversial compounds used in aquaculture, due to the risks it poses to the consumers, including its effects on the liver as well as its genotoxic potentials, apoptosis and DNA damage. Overall, the obtained results show that $\mathrm{MG}$ is strongly toxic according to approximate doses of edible fish, so no safe level for the presence of $\mathrm{MG}$ and $\mathrm{LMG}$ in fish for human consumption could be established, but $\mathrm{MG}$ and its residues in the eatable tissue of fish could not be ignored due to their suspected tumorigenicities and carcinogenic properties, posing a potential risk for human consumption. This problem seems that caution should be taken when fish from uncertain resources are consumed. Finally, more extensive assessment of malachite green is warranted in Egypt.

\section{References}

Bancroft JD and Gamble M (2008): Theory and practice of histological techniques. $6^{\text {th }}$ ed. Churchill Livingstone Elsevier; Philadelphia, PA.

Belfield A and Goldberg DM (1971): Hydrolysis of adenosine- monophosphate by acid phosphatase as measured by a continuous spectrophotometric assay. Enzyme, 12: 561566

Bose B, Motiwale L, and Rao KV (2005): DNA damage and G2/M arrest in Syrian hamster embryo cells during Malachite green exposure are associated with elevated phosphorylation of ERK1 and JNK1. Cancer Lett., 230: 260270.

Botros SS, Mahmoud MR, Moussa MM, et al., (2007): Immunohistopathological and biochemical changes in schistosoma mansoni-infected rat treated with artemether. J Infection, 55: 47477.

Bradford MM (1976): A rapid and sensitive method for the quantization of microgram quantities of 
protein utilizing the principle of protein-dye binding. Anal Biochem, 7: 248-254.

Cha CJ, Doerge DR, and Cerniglia CE (2001): Biotransformation of malachite green by the fungus cunninghamella elegans. Appl Environ Microbiol, 67: 4358-4360.

Chang CF, Yang CH, Shu YO, et al., (2001): Effects of temperature, salinity and chemical drugson the in vitro propagation of the dinoflagellate parasite,Amylodinium ocellatum. Asian Fish Soc, P31.

Clemmensen S, Jensen JC, Jensen NJ, et al., (1984): Toxicological studies on malachite green: a triphenylmethane dye. Archives of Toxicology; 56(1): 43- 45.

Culp S and Beland F (1996): Malachite green: a toxicological review. J Am Clin Toxicol, 15: 219-238.

Culp SJ, Beland FA, Heflich RH, et al., (2002): Mutagenicity and carcinogenicity in relation to DNA adduct formation in rats fed leucomalachite green, Mut. Res. Fundamental and Molecular Mechanisms of Mutagenesis 506, 55-63.

Culp SJ, Blankenship LR, Kusewitt DF, et al., (1999): Toxicity and metabolism of malachite green and leucomalachite green during short-term feeding to Fischer 344 rats and B6C3F1 mice. Chemico-Biological Interactions 122(3), 153170.

Culp SJ, Mellick PW, Trotter RW, et al., (2006): Carcinogenicity of malachite green chloride and leucomalachite green in $\mathrm{B} 6 \mathrm{C} 3 \mathrm{~F} 1$ mice and F344 rats. Food Chem Toxicol, 44: 12041212.

Das JK, Sarkar S, Sk UH, et al., (2013): Diphenylmethyl selenocyanate attenuates malachite green induced oxidative injury thropgh antioxidation \& inhibition of DNA damage in mice. Indian J Med Res 137, June, 1163-1173.

De Angelis I, Giuliano Albo A, Nebbia C, et al., (2003): Cytotoxic effects of malachite green in two human cell lines, Toxicol. Lett; 144: 58.

Doerge DR, Churchwell MI, Gehring TA, et al., (1998): Analysis of malachite green and metabolites in fish using liquid chromatography atmospheric pressure chemical ionisation mass spectrometry. Rapid Commun Mass Spectrom. 12 (21), 16251634.

Donya SM, Farghaly A, Abo-Zeid MA, et al., (2012): Malachite green induces genotoxic effect and biochemical disturbances in mice. European Review for Medical and Pharmacological Sciences, 16: 469-482.
Fessard V, Godard T, Huet S, et al., (1999): Mutagenicity of Malachite green and leucomalachite green in in vitro tests. J Appl Toxicol, 19: 421-430.

Food Safety Commission of Japan (FSCJ, 2007): Summary of evaluation report of malachite green and leucomalachite green conducted by the Food Safety Commission of Japan, working document.

Food Standards Australia New Zealand (FSA 2005): Report on a survey of chemical residues in domestic and imported aquacultured fish. 33.

Gupta S, Sundarrajan M, and Rao KV (2003): Tumor promotion by metanil yellow and malachite green during rat hepatocarcinogenesis is associated with dyes regulated expression of cell cycle regulatory proteins. Teratogenesis, Carcinogenesis and Mutagenesis.1:301-312.

Hameed BH and El-Khaiary MI (2008): Kinetics and equilibrim studies of malachite green adsorption on rice straw-derived char. J Hazard Mater, 153:701-708.

Henderson AI, Schmitt TC, Heinze TM, et al., (1997): Reduction of malachite green to leucomalachite green by intestinal bacteria. Appl Environ Microbiol, 63: 4099-4101.

Hidayah N, Abu Bakar F, Mahyudin NA, et al., (2013): Detection of malachite green and leucomalachite green in fishery industry. International Food Research Journal 20(4): 1511-1519.

Hushcha T, Luik A, and Naboka YN (2000): Conformation changes of albumin in its interaction with physiologically active compounds as studied by quasielastic light scattering spectroscopy and ultrasonic method. Talanta , 53: 29-34.

Jamil K (2001): Bioindicators and biomarkers. In: Enviromental pollution and risk assessment, science publishers,inc., Enfield(NH).USA and plymouth(UK),pp45-52.

Jeong JU (2005): Cancer-causing chemical found in local farm fish. The Korea Times, 6 .

Jiang Y, Xie P, and Donghu GL (2009): Distribution and depuration of the potentially carcinogenic malachite green in tissues of three freshwater farmed Chinese fish with different food habits. Aquaculture, 288:1-6.

Kassie F, Parazfall W, and Knasmuller S (2000): single cell gel electrophoresis assay: a new technique from human biomonitoring studies. Mutat Res., 413: 33-38.

Kumar M, Samarth R, Selvan SR, et al., (2007): Protective effect of adhatoda vascianees against radiation-induced damage at cellular, biochemical and chromosomal levels in swiss albino mice. Evid Based Complement Alternat Med, 371:25. 
Li RH and Hotchkiss JH (1995): Potential genotoxicity of chronically elevated nitric oxide: a review. Mutat Res, 339: 73-89.

Máchová J, Svobodová Z, Svobodník J, et al., (1996): Persistence of malachite green in tissues of rainbow trout after a long-term therapeutic bath. Acta Vet Brno, 65: 151-159.

Mahudawala D, Redkar A, Wagh A, et al. (1999): Malignant transformation of Syrian hamster embryo (she) cells in culture by malachite green: an agent of environmental importance.Indian J Exp Biol, 37: 904-918.

Manjanatha MG, Shelton SD, Bishop M, et al., (2004): Analy-sis of mutations and bone marrow micronuclei in Big Bluerats fed leucomalachite green. Mutation researchFundamental and Molecular Mechanism of Mutagenesis, 547 (1-2): 5-18.

Min M and Wilk-Zasadna I (2007): Effects of malachite green and its major metabolite, leucomalachite green, in micromass cultures of rat embryonic cells. Bull Vet Inst Pulawy; 51:695-700.

Mitrowska K and Posyniak A (2004): Determination of malachite green and its metabolite, leucomalachite green, in fish muscle by liquid chromatography Bulletin of the Veterinary Institute in Pulawy, 48, 173-176

Mitrowska K, Posyniak A, and Zmudzki J (2007): The effects of cooking on residues of malachite green and leucomalachitegreen in carp muscles. Anal Chim Acta, 586: 420-425.

Mittelstaedt RA, Mei N, Webb PJ, et al., (2004): Genotoxicity of malachite green and leucomalachite green in female big blue b6c3f1 rat. Mutat Res, 561: 127-138.

Mustacich D and Powis G (2000): Thioredoxin reductase. Biochem J, 346: 1-8.

Naravaneni R and Jamil K (2005): Cytogenic biomarkers of carbofuran toxicity utilizing human lymphocyte cultures invitro. Drug and Chemical Toxicology, 28: 359-372.

National Toxicology Program (NTP) (2005): "Toxicology and carcinogengesis studies of ma-lachite green chloride and leucomalachite green in $\mathrm{f} 344 / \mathrm{n}$ rats and b6c3f1 mice (feed studies)" p.o. box 12233 research triangle park, nc 27709 ntp tr 527 nih publication no. 05-4463 u.s. department of health and human services public health service national institutes of health.

Olesen PT, Larsen JC, and Schnipper A (2007): Risk assessment of malachite green in food. Report of the National Food Institute, Technical University of Denmark, 35.

Onell ZY, Alit D, Hongshan W, Zhrong W, et al. (2000): Emodin on hepatic fibrosis in rats. Chinese Medical Journal, 113: 599- 601.
Perandones CE, Illera VA, Peckham D, et al. (1993): Regulation of apoptosis in vitro in maturemurine spleen $\mathrm{t}$ cells. $\mathrm{J}$ Immunol, 151:3521-3529.

Pohjala L, Tammela P, Samanta SK, et al. (2007): Assessing the data quality in predictive toxicology using a panel of cell lines and cytotoxicity assays. Anal Biochem, 362: 221228.

Prasenjit D, Katoch RC, Subhas V, et al., (2006): Drug sensitivity of gram positive bacteria from fish fauna of Himachal Pradesh. Indian Vet. J. 78 (7): 576-578.

Radko L, Minta M, and Stypuła-Trębas S (2011): Cellular toxicity of malachite green and leucomalachite green evaluated on two rat cell lines by MTT, NRU, LDH, and protein assays. Bull Vet Inst Pulawy 55: 347-353.

Retiman S and Frankel S (1957): Colorimetric method for the determination of serum glutamic oxaloacetic acid and glutamic pyruvic transaminases. Am J Clin Pathol, 28: 56-65.

Santos RFB, Dias HM, and Fujimoto RY (2012): Acute toxicity and histopathology in ornamental fish amazon bluespotted corydora (Corydoras melanistius) exposed to formalin. Anais da Academia Brasileira de Ciências, 84 (4): 1001-1007

Schwaiger J, Wanke U, Adam S, et al., (1997): The use of histopathological indicators to evaluate contaminant-related stress in fish. J Aquat Ecosyst Stress and Recov 6: 75-86.

Srivastava S, Sinha R, and Roy D (2004): Toxicological effects of malachite green. aquat toxicol, 66: 319-329.

Stammati A, Nebbia C, Angelis ID, et al. (2005): Effects of malachite green (MG) and its major metabolite, leucomala-chite green (LMG), in two human cell lines, Toxicol in Vitro, 19: 853-858.

Tripathi M, Khanna SK, and Das M (2007): Surveillance on use of synthetic colours in eatables vis Prevention of Food Adulteration Act of India. Food Control, 18: 211-219.

Yosida, T H and Amano, K (1965): Autosomal polymorphism in laboratory bred and wild norway rats, rattus norvegicus. Chromosoma, 16: 658-667.

Zahn T and Braunbeck T (1995): Cytotoxic effects of sublethal concentrations of malachite green in isolated hepatocytes from rainbow trout (oncorhynchus mykiss). Toxicol In Vitro, 9: 729-741.

Zar JH (1999): Biostatistical analysis, 4, (Prentice Hall, Upper Saddle River, N J,). 662, plus appendices. 


\section{الملخص العربي}

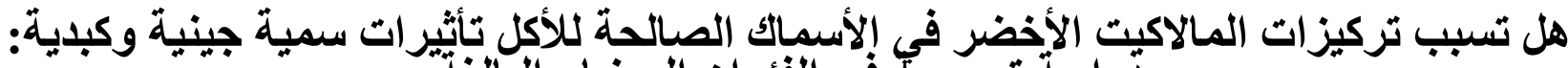

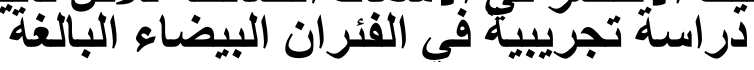

\section{نيرمين عدلي حسن و فاروق صادق الجندي 1 و عائشة المنسي2}

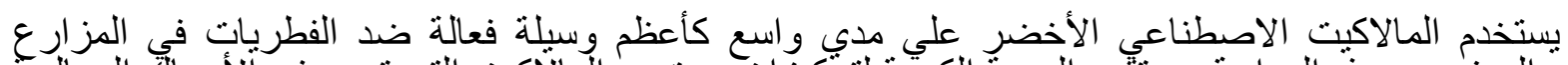

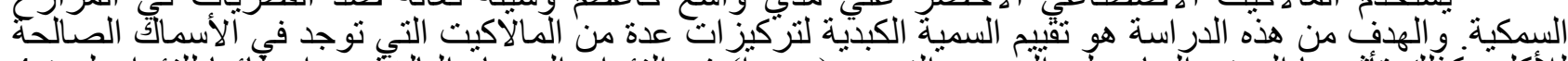

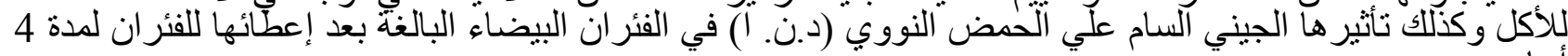

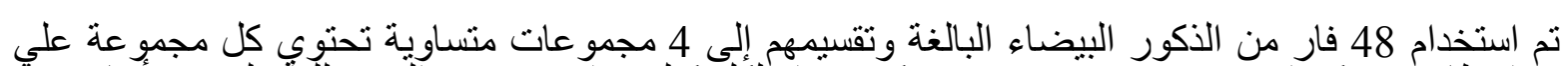

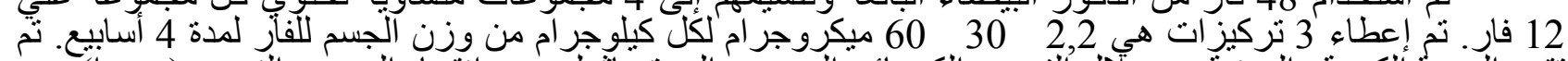

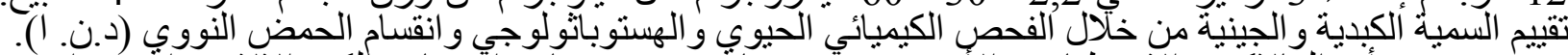

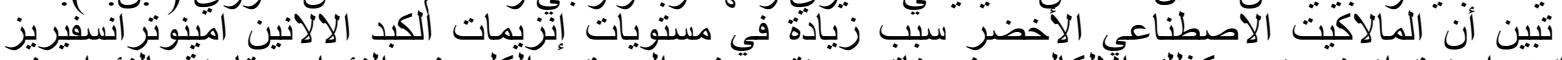

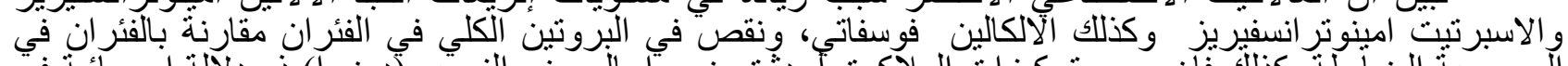

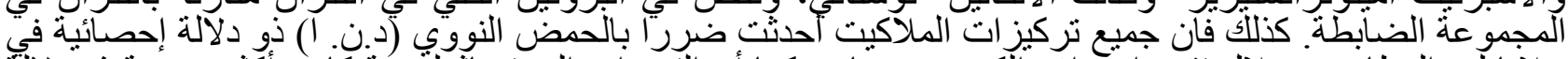

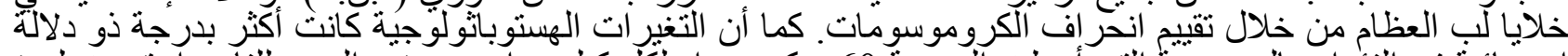

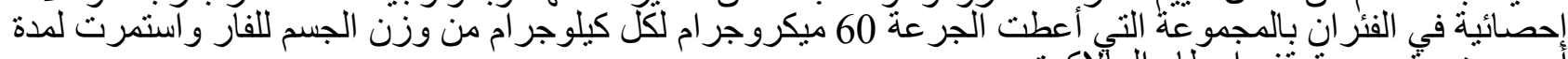

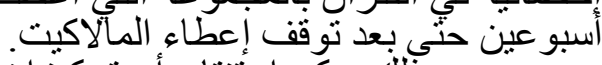

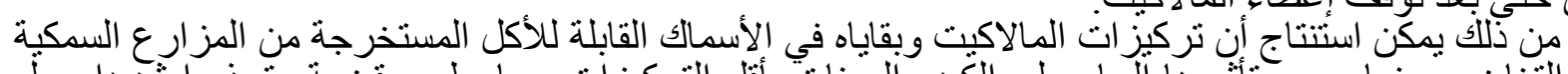

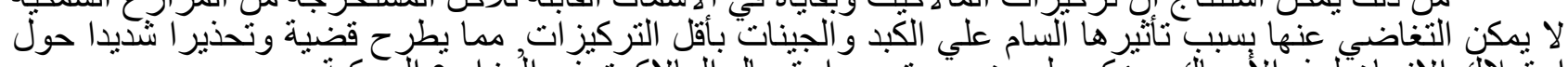

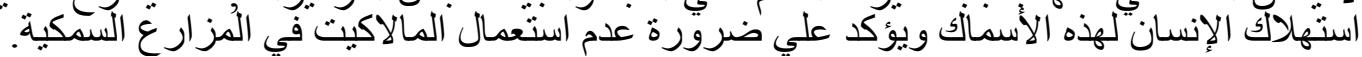

1 قسم الطب الشرعي و السموم الإكلينيكية كلية الطب جامعة بنها

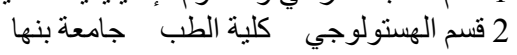

